\title{
Whole-body and splanchnic amino acid metabolism in sheep during an acute endotoxin challenge
}

\author{
C. J. McNeil ${ }^{1,2}$, S. O. Hoskin ${ }^{1,3}$, D. M. Bremner ${ }^{1}$, G. Holtrop ${ }^{4}$ and G. E. Lobley ${ }^{1 *}$ \\ ${ }^{1}$ Rowett Institute of Nutrition and Health, University of Aberdeen, Foresterhill, Aberdeen AB25 2ZD, UK \\ ${ }^{2}$ Aberdeen Biomedical Imaging Centre, University of Aberdeen, Foresterbill, Aberdeen AB25 2ZD, UK \\ ${ }^{3}$ Fiber Fresh Feeds Ltd, RD2, Reporoa, 3083, New Zealand \\ ${ }^{4}$ Biomathematics and Statistics Scotland, Aberdeen AB25 2ZD, UK \\ (Submitted 25 February 2016 - Final revision received 7 April 2016 - Accepted 8 April 2016 - First published online 18 May 2016)
}

\section{Abstract}

Supplemented protein or specific amino acids (AA) are proposed to help animals combat infection and inflammation. The current study investigates whole-body and splanchnic tissue metabolism in response to a lipopolysaccharide (LPS) challenge with or without a supplement of six AA (cysteine, glutamine, methionine, proline, serine and threonine). Eight sheep were surgically prepared with vascular catheters across the gut and liver. On two occasions, four sheep were infused through the jugular vein for $20 \mathrm{~h}$ with either saline or LPS from Escherichia coli ( $2 \mathrm{ng} / \mathrm{kg}$ body weight per $\mathrm{min}$ ) in a random order, plus saline infused into the mesenteric vein; the other four sheep were treated with saline or LPS plus saline or six AA infused via the jugular vein into the mesenteric vein. Whole-body AA irreversible loss rate (ILR) and tissue protein metabolism were monitored by infusion of [ ring- $^{2} \mathrm{H}_{2}$ ]phenylalanine. LPS increased $(P<0 \cdot 001)$ ILR $(+17 \%)$, total plasma protein synthesis $(+14 \%)$ and lymphocyte protein synthesis $(+386 \%)$ but decreased albumin synthesis $(-53 \%, P=0 \cdot 001)$, with no effect of AA infusion. Absorption of dietary AA was not reduced by LPS, except for glutamine. LPS increased the hepatic removal of leucine, lysine, glutamine and proline. Absolute hepatic extraction of supplemented AA increased, but, except for glutamine, this was less than the amount infused. This increased net appearance across the splanchnic bed restored arterial concentrations of five AA to, or above, values for the saline-infused period. Infusion of key AA does not appear to alter the acute period of endotoxaemic response, but it may have benefits for the chronic or recovery phases.

Key words: Endotoxin lipopolysaccharide: Amino acids: Protein synthesis: Splanchnic tissues: Sheep

Infection or inflammation causes marked responses in amino acid (AA) and protein metabolism. These include alterations in plasma AA concentrations, with many being decreased $^{(1-3)}$, plus accompanying changes in whole-body AA irreversible loss rates (ILR) ${ }^{(1,3,4)}$. These responses probably reflect complex interactions between the immune system and key regulatory organs. For example, lowered AA plasma concentrations may result from reduced net absorption, either from the inhibition of intake that accompanies inflammation and sepsis ${ }^{(5)}$ or increased oxidation by the portal-drained viscera (PDV), as observed with certain gastrointestinal infections ${ }^{(6)}$. Alternatively, demands within specific tissues can increase the removal of AA from the blood circulation to support the synthesis of either additional proteins or specific metabolites. For example, manufacture of positive acute-phase proteins increases liver utilisation of essential $\mathrm{AA}^{(4)}$, especially phenylalanine ${ }^{(7)}$, whereas elevated hepatic glucose synthesis during major stress ${ }^{(8)}$ elevates metabolism of glucogenic AA, although this is not always observed $^{(4)}$. Similarly, production of additional glutathione to provide antioxidant protection adjacent to sites of inflammation and pro-oxidant activity can alter the demand for cysteine ${ }^{(9)}$. Furthermore, activation of the immune system elevates the net use of AA to support proliferative responses associated with infection or surgery ${ }^{(10)}$, and it also increases the hepatic use of glutamine $^{(4)}$, a known regulator of intermediary metabolism ${ }^{(11)}$. Although some of these needs are general and require most AA, as in the case of cellular proliferation, other reactions will be restricted to one, or just a few, AA and this will leave the remainder in disproportionate excess and lead to their disposal as urea and lead to the net $\mathrm{N}$ losses characteristic of inflammation and sepsis ${ }^{(12)}$.

Reduced plasma AA during infection or inflammation can be offset by either additional protein or AA supply ${ }^{(13)}$, but the quantities required differ between $\mathrm{AA}^{(3)}$ and between type and magnitude of the challenge ${ }^{(2)}$. The effectiveness of such approaches has been demonstrated in septic rodents, in which

Abbreviations: AA, amino acids; FSR, factional synthesis rate; ILR, irreversible loss rate; LPS, lipopolysaccharide; PDV, portal-drained viscera.

* Corresponding author: G. E. Lobley, email g.lobley@abdn.ac.uk 
a cocktail of AA reduces the severity of the challenge and enhances the rate of recovery ${ }^{(14)}$. Future nutritional strategies to help combat the deleterious effects of infection and inflammation and to aid recovery require knowledge of both the absolute demands for specific $\mathrm{AA}^{(3)}$ and where in the body these requirements arise. The effectiveness of targeted intervention in sheep, on the basis of previous kinetic quantification of AA demands during the acute phase of an inflammatory challenge ${ }^{(3)}$, is addressed in the current study. The focus is on splanchnic tissue metabolism, with consequences on absorption, liver-related protein metabolism and net AA supply to peripheral tissues. This was tested with a cocktail of six AA, based on information gained from an earlier study ${ }^{(3)}$. Three (methionine, serine and threonine) were chosen because the ILR through plasma decreased markedly in response to lipopolysaccharide (LPS $)^{(3)}$, suggestive of a deficient supply during endotoxaemia. Cysteine has been reported as beneficial for septic rats ${ }^{(14)}$ and LPS-challenged pigs ${ }^{(15)}$ but showed no change in ILR in the previous sheep study ${ }^{(3)}$. Also included was proline, which showed similar responses to cysteine, with no effects on ILR but marked decreases in plasma concentration under an LPS challenge ${ }^{(3)}$. The final AA in the cocktail was glutamine, the supplementation of which is often used in clinical situations ${ }^{(16)}$ and exhibits increased turnover during cancer $^{(17)}$ and endotoxin challenge ${ }^{(3)}$. For all these AA, the amounts infused were based on the product of their ILR and the fractional reduction in plasma concentration, as observed under similar experimental conditions previously ${ }^{(3)}$.

\section{Methods}

\section{Sheep and diets}

All procedures were approved by the Ethical Review Committee of the Rowett Institute of Nutrition and Health and conformed to UK legislation under the Animals (Scientific Procedures) Act 1986. Suffolk cross lambs (eight lambs, two female, six castrate male; 12-16 months old, 37-54 kg live weight) were prepared with silicone rubber catheters in the aorta, mesenteric vein, portal vein and hepatic vein ${ }^{(18)}$. During the 2 -week recovery period from surgery, the sheep were offered a mixed roughage-concentrate diet (daily $2 \times 500 \mathrm{~g}$ as fed) with the following composition ( $\mathrm{g} / \mathrm{kg}$ as fed): hay 500 , barley 300, molasses 100 , fishmeal 90 , vitamin and mineral mix $10(2 \times 500 \mathrm{~g} / \mathrm{d}$ as fed $) ; 830 \mathrm{~g} \mathrm{DM} / \mathrm{kg} ; 21.3 \mathrm{~g} \mathrm{~N} / \mathrm{kg} \mathrm{DM}, 11.0 \mathrm{MJ}$ metabolisable energy/kg DM, at an estimated $1 \cdot 0-1 \cdot 3 \times$ energy maintenance based on metabolic body weight $\left(\mathrm{kg}^{0.75}\right)$. Subsequently, they were acclimatised over 1 week to metabolism crates, with the daily feed provided as $24-\mathrm{h}$ portions, and then allocated to treatments when a temporary polyvinyl catheter was inserted into the jugular vein ${ }^{(18)}$.

At treatment allocation, the sheep ( $n$ 8) were divided between two groups, balanced for sex and weight. Within each group, the sheep were measured on 2 experimental days, $7 \mathrm{~d}$ apart. For group A $(n 4)$, the 2 infusion days involved either sterile $0 \cdot 15 \mathrm{~m}$-sodium chloride (control) infused into both the jugular vein $(15 \mathrm{~g} / \mathrm{h})$ and mesenteric vein $(40 \mathrm{~g} / \mathrm{h})$ for $20 \mathrm{~h}$, whereas for the other experimental day the jugular vein infusion ( $15 \mathrm{~g} / \mathrm{d}$ ) involved LPS (from Escherichia coli 155, serotype 055:B5, $2 \mathrm{ng} / \mathrm{min}$ per $\mathrm{kg}$ body weight (BW)), as described previously $^{(3)}$. For group B $(n$ 4), 1 experimental day was identical to the control procedure used for group A, whereas the other experimental day involved a jugular vein infusion of LPS, identical to group A, plus a sterile mixture of AA into the mesenteric vein $(40 \mathrm{~g} / \mathrm{h}$ ). The order of infusions (saline $v$. LPS, with or without AA) was randomised between sheep. Therefore, all eight sheep received a control (saline) jugular infusion, whereas four received LPS as a treatment and four received LPS plus AA. The amounts for each of the AA infused were calculated from the product of their ILR and the fractional decrease in arterial concentration from control value in response to a similar dose of LPS, both as reported previously ${ }^{(3)}$. For sheep with a $\mathrm{BW}$ of $50 \mathrm{~kg}$, the concentrations of AA-N in the supplement were cysteine $(68 \mathrm{~mm})$, glutamine $(320 \mathrm{~mm})$, methionine $(38 \mathrm{~mm})$, proline $(64 \mathrm{~mm})$, serine $(124 \mathrm{~mm})$ and threonine $(138 \mathrm{~mm})$ dissolved in $0.15 \mathrm{~m}$-sodium chloride. For sheep of other weight, the concentration of the infusate was adjusted based on $\mathrm{BW}^{0.75}$.

Just before the start of each 20-h infusion period, a background blood sample was taken for evaluation of clinical parameters (including blood $\mathrm{Hb}$, plasma albumin, leucocytes count and cell type distribution) and determination of blood and plasma DM (by freeze-drying, each in triplicate). In order to measure plasma flow across the splanchnic tissues, sterile sodium $p$-aminohippurate $(0.1 \mathrm{~m}$ prepared in $0.05 \mathrm{~m}$-sodium phosphate buffer $\mathrm{pH} 7.4$ ) containing $250 \mathrm{IU} / \mathrm{g}$ heparin (Leo Laboratories) was also infused at a rate of $40 \mathrm{~g} / \mathrm{h}$ into the mesenteric vein over a period of $15-20 \mathrm{~h}$. This was mixed with the appropriate AA or $0.15 \mathrm{M}$-sodium chloride infusate via a t-piece connector. From 12 to $20 \mathrm{~h}$, a solution of $15 \mathrm{~mm}-\left[{ }^{2} \mathrm{H}_{5}\right]$ phenylalanine (99at\%; Cambridge Isotope Laboratories) in $0 \cdot 15 \mathrm{~m}$ sterile saline was infused at $10 \mathrm{~g} / \mathrm{h}$ into the jugular vein, again via a t-piece connector.

Between 16 and $20 \mathrm{~h}$ of LPS infusion, blood was withdrawn continuously over iced water as $4 \times 1 \mathrm{~h}$ samples from the arterial, portal and hepatic venous catheters ${ }^{(18)}$, with $12 \mathrm{ml}$ taken for each collection. At 12 and 20 h, $20 \mathrm{ml}$ of arterial blood was withdrawn and maintained at room temperature for immediate processing of lymphocytes. At $20 \mathrm{~h}$, the various infusions were stopped and $6 \mathrm{~g}$ of a sterile saline containing $24 \mathrm{mg}$ of Evan's Blue was injected via the jugular catheter. Then, $2.5 \mathrm{ml}$ of blood was withdrawn at 3, 6, 9 and $12 \mathrm{~min}$ after injection to allow the estimation of plasma volume ${ }^{(19)}$.

\section{Chemical analyses}

Clinical blood parameters were determined as described previously ${ }^{(3)}$. Immediately following each hourly collection, blood analysis $\left(\mathrm{pH}, \mathrm{pO}_{2}, \mathrm{pCO}_{2}\right.$ and $\left.\mathrm{Hb}\right)$ was performed with an ABL650 Blood Gas Analyser (Radiometer) and packed cell volume was determined using a microcentrifuge. Blood samples were then centrifuged at $1000 \boldsymbol{g}$ for $15 \mathrm{~min}$, and the plasma was used for various analyses using gravimetric procedures ${ }^{(18)}$. All blood samples taken were analysed individually, parameters were then calculated separately for each hour of collection and then the mean of these was used for statistical analysis. 
The $p$-aminohippurate concentration was quantified on $0.7 \mathrm{~g}$ of plasma ${ }^{(18)}$, whereas $1 \mathrm{~g}$ of plasma from each sample site was retained for enrichment analysis of $\left[{ }^{2} \mathrm{H}_{5}\right]$ phenylalanine. To another $1.4 \mathrm{~g}$ of plasma was added $0.6 \mathrm{~g}$ of a mixture of $\left[\mathrm{U}^{-13} \mathrm{C}\right]$ algal hydrolysate containing $\left[5^{-15} \mathrm{~N}\right]$ glutamine, [indole- $\left.{ }^{15} \mathrm{~N}\right]$ tryptophan, $\left[1-{ }^{13} \mathrm{C}\right]$ cysteine and $\left[{ }^{15} \mathrm{~N}_{2}\right]$ urea to allow the determination of AA concentrations by isotope dilution ${ }^{(20,21)}$. This sample was divided into two equal portions, with one kept in reserve. A further portion of fresh plasma ( $0.4 \mathrm{~g})$ was analysed with commercial kits for total protein, albumin, glucose (kits 981-387, 981-767, 981-304, respectively; Thermo Scientific), ammonia (kit 17660; Sentinel Diagnostic) and lactate (kit 735-10; Trinity Biochemicals) on a clinical analyser (Kone Limited). Plasma albumin was isolated from arterial plasma ${ }^{(22)}$. Concentrations of Evans Blue bound to plasma protein were determined spectrophotometrically ${ }^{(19)}$ and values were extrapolated to zero time injection to allow the estimation of plasma volume. Determination of the enrichments of plasma free $\left[{ }^{2} \mathrm{H}_{5}\right]$ phenylalanine and the extraction, hydrolysis and analysis of both albumin and plasma total protein labelled with $\left[{ }^{2} \mathrm{H}_{5}\right]$ phenylalanine were performed as described previously ${ }^{(22)}$. Lymphocytes were isolated from the 20-ml blood samples taken at the start and end of the isotope infusion. The blood was first gently diluted $1: 1$ with $0 \cdot 15 \mathrm{~m}-\mathrm{NaCl}$, and $5-\mathrm{ml}$ portions were slowly layered onto $5 \mathrm{ml}$ of Histopaque 1077 lymphocyte separation medium (Sigma Bioscience), in eight separate tubes, with care taken to avoid mixing of the two layers. The tubes were then centrifuged at $700 \boldsymbol{g}$ for $20 \mathrm{~min}$ at $20^{\circ} \mathrm{C}$ with no brake applied. The lymphocyte layer at the interface was then carefully removed from each tube using a Pasteur pipette and was transferred to a $10-\mathrm{ml}$ glass hydrolysis tube and diluted to $10 \mathrm{ml}$ with ice-cold $0 \cdot 15 \mathrm{~m}-\mathrm{NaCl}$ saline. This solution was centrifuged at $1500 \mathrm{~g}$ for $15 \mathrm{~min}$ at $4^{\circ} \mathrm{C}$, and the pellet was resuspended in $4 \mathrm{ml}$ of ice-cold lysis buffer $(9: 1(\mathrm{v} / \mathrm{v})$ ammonium chloride $(8.3 \mathrm{~g} / \mathrm{l}): \quad 0.17 \mathrm{M}$-Tris-HCl buffer $\mathrm{pH}$ 7.65). This was recentrifuged at $1500 \mathrm{~g}$ for $15 \mathrm{~min}$ at $4{ }^{\circ} \mathrm{C}$, and the supernatant containing the contents from erythrocyte lysis was decanted. The pellet was then washed with ice-cold saline and recentrifuged on three more occasions. After the final wash, the pellet was resuspended in $5 \mathrm{ml}$ of distilled water and stored frozen at $-20^{\circ} \mathrm{C}$ until further analysis. Lymphocyte protein was prepared in a manner similar to the general procedure for albumin and total plasma protein and involved thawing the stored suspension and deproteinisation with the addition of $0.8 \mathrm{ml}$ of $48 \%(\mathrm{w} / \mathrm{v})$ sulphosalicylic acid (SSA). After allowing the sample to stand on ice for $10 \mathrm{~min}$, it was centrifuged at $1500 \mathrm{~g}$ for $20 \mathrm{~min}$ at $4^{\circ} \mathrm{C}$. The sample was then washed twice with $8 \mathrm{ml}$ of $8 \%$ ice-cold SSA and centrifuged on each occasion. The supernatant was removed and to the pellet a phenol crystal was added (to protect aromatic AA against oxidation) followed by $4 \mathrm{ml}$ of $4 \mathrm{M} \mathrm{HCl}$. This was then hydrolysed for $18 \mathrm{~h}$ at $105^{\circ} \mathrm{C}$ in a heating block. Subsequent steps were then performed as described previously ${ }^{(22)}$

\section{Calculations}

Plasma flows $(\mathrm{kg} / \mathrm{min})$ were determined by a gravimetric approach $^{(18)}$ with blood flow calculated from plasma flow/(1-packed cell volume). Hepatic artery ( $F A$ ) flow (blood or plasma) was determined as the difference between the flows in the hepatic vein $(F H)$ and hepatic portal vein $(F P)$. The plasma and blood water flows were calculated from the DM in order to quantify urea transfers ${ }^{(23)}$. In general, net mass transfers $(\mu \mathrm{mol} / \mathrm{min}$ ) of individual AA or metabolites across the PDV were calculated as follows:

$$
\left(C_{b} \times F H\right)-\left(C_{p} \times F P\right)-\left(C_{a} \times F A\right),
$$

where $C_{a}, C_{p}$ and $C_{b}$ are metabolite concentrations ( $\mu \mathrm{mol} / \mathrm{kg}$ ) in arterial, hepatic portal vein and hepatic vein fluids (blood for $\mathrm{O}_{2}$, ammonia; blood water for urea; plasma for all other measurements).

For protein synthesis ( $\mu \mathrm{mol} / \mathrm{min}$ ), estimates based on isotope transfers across the gastrointestinal tract and liver the appropriate calculations were as follows:

across the PDV:

$$
\left(C_{p} \times E_{p}-C_{a} \times E_{a}\right) \times F P / E_{x},
$$

and across the liver:

$$
\frac{\left(C_{b} \times E_{b} \times F H\right)-\left(C_{p} \times E_{p} \times F P\right)-\left(C_{a} \times E_{a} \times F A\right)}{E_{x}},
$$

where $E_{b}, E_{p}$ and $E_{a}$ are the respective enrichments (molar \% excess) of free $\left[{ }^{2} \mathrm{H}_{5}\right]$ phenylalanine in plasma from the hepatic vein, portal vein and artery, and where $E_{x}$ is the enrichment value selected as representative of the precursor pool. For comparison with whole-body ILR measurements, $E_{x}$ was based on the arterial value, but for other comparisons $E_{x}$ was assumed to be similar to hepatic venous enrichments, as this has been shown to reflect well values for export proteins ${ }^{(22)}$. Both estimates of precursors, however, are less than values observed in the intracellular pools of either the liver $^{(22)}$ or the gastrointestinal tract ${ }^{(24)}$. For both net transfer data and isotope kinetics, the concentrations, enrichments and flows were calculated for each individual hour of collection and then averaged.

Whole-body ILR $(\mathrm{mmol} / \mathrm{h})$ of the tracee was estimated by the standard procedure - that is

$$
=\left(99 / E_{a}-1\right) \times \text { infusion rate }(\mathrm{mmol} / \mathrm{h}),
$$

where 99 is the enrichment (molar \% excess) of the $\left[{ }^{2} \mathrm{H}_{5}\right]$ phenylalanine infusate.

Enrichments for both total protein and albumin from plasma were altered in a linear manner over the times of collection, and their respective gradients (change molar \% excess/h) were divided by $E_{h}$ (representative of the precursor for export proteins ${ }^{(22)}$ ) and adjusted to give daily fractional synthesis rates (FSR). These FSR were then converted to absolute synthesis rates $(\mathrm{g} / \mathrm{d})$ by

$$
\text { FSR/100 } \times \text { plasma concentration }(\mathrm{g} / \mathrm{l}) \times \text { plasma volume }(\mathrm{l}),
$$

where total plasma volume was determined by dilution of Evans Blue $^{(19)}$. For lymphocytes, a value of $28 \cdot 2 \mathrm{pg}$ protein/cell

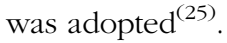




\section{Power calculations and statistical analyses}

The number of sheep per treatment group (control combined with LPS or control combined with LPS + AA) was based on comparing the effect of LPS + AA with the effect of LPS alone. The power calculations were performed at a power of $80 \%$ for the $5 \%$ significance level, with the between-sheep variance obtained from previous studies ${ }^{(3,22)}$. A considerable number of parameters were to be assessed in this study, but the decision on the number of sheep per treatment group was based on the following two outcomes that were deemed most indicative of the restorative effect of AA supplementation on an LPS challenge. The first parameter involved restoration of the arterial concentrations for the six AA infused in combination with LPS to at least $90 \%$ of the control (saline) values. Expected decreases for these six AA were expected to be $23-73 \%$ by the action of LPS alone ${ }^{(3)}$ with between-sheep sD 13-43\% of control values $^{(3)}$ yielding $n 4$ per treatment group. The second parameter involved changes in FSR for plasma albumin, a negative acute-phase protein, and based on an SD of $0.49 \% / \mathrm{d}^{(22)}$ a change of $1.4 \% / \mathrm{d}$, equivalent to the difference between fed and fasted sheep ${ }^{(22)}$, would be observed with $n 4$ per treatment group. Additional power was gained by initial selection of six sheep per treatment group. Unfortunately, one sheep required to be euthanised during the surgical procedure, whereas three others developed non-patent catheters in either the portal or hepatic veins before the end of the study. Thus, eleven sheep had measurements reliant on arterial samples (this included the two criteria used for the power calculations above), but only four sheep per treatment group were used for the full splanchnic transfers. In practice, the changes based on arterial values only were similar between the eleven and eight sheep comparisons. Therefore, for the main text, data are presented for the eight sheep that had the full working splanchnic-bed catheters. Of these, four received a saline infusion or LPS infusion on 2 separate days. The other four sheep received a saline infusion or LPS + AA infusion on 2 separate days. The order of infusions was randomised within each group. Although this is a small study, the use of a frequent feeding regimen, continuous administration of a low dose of LPS over the experimental duration and collection of integrated blood samples all helped reduce the associated variance and meant that fewer animals were needed to detect statistical differences. In addition, where appropriate, results from the eleven sheep are presented as the online Supplementary Material.

Data were analysed as a mixed model using the residual maximum likelihood (REML) estimation procedure in Genstat 13th edition, release 13.2 (VSN International). The influence of LPS (independent of whether AA were infused or not) was assessed with sheep and period (experimental day) within sheep as random effects, whereas period and LPS status (present or absent) and their interaction were regarded as fixed effects. To assess the influence of AA infusion, sheep and period within sheep were considered as random effects, whereas period and treatment and their interaction were considered as fixed effects, where treatment involved saline, LPS and LPS + AA infusions.

All data are presented as predicted means from the REML analysis, with the maximum standard error of the difference between means value also given for the various comparisons. $P<0.05$ was taken as evidence of a significant response and $0 \cdot 05<P<0 \cdot 10$ as weak evidence.

\section{Results}

\section{Whole-body responses and arterial concentration changes}

Within the first $4 \mathrm{~h}$ of LPS infusion, there were increases in body temperature $\left(1 \cdot 0-2 \cdot 0^{\circ} \mathrm{C}\right)$ and respiration rate, as observed previously $^{(3)}$. During the same period, occasionally there were mild reluctances to eat, but this never exceeded more than two-hourly meals; the meals were consumed soon thereafter, and thus for the total $20 \mathrm{~h}$ there were no refusals. Over the period of blood collection (16-20 h after the start of LPS or vehicle infusion), endotoxaemia did not affect either arterial blood $\mathrm{pH}$ or $\mathrm{Hb}$ status (data not shown). Hb was lower during the second period (10.7 v. 9.1, SED 0.61, $P=0.027)$, as was plasma albumin $(27 \cdot 1 v .26 .5 \mathrm{~g} / \mathrm{l}$, SED $0 \cdot 22, P=0 \cdot 013$ ), both possibly related to the amount of blood withdrawn over the various procedures. Blood leucocyte numbers were slightly increased just before LPS infusion for the second period (10.24 v. $12.25 \times 10^{9}$ cells/1 blood, SED 0.870, $\left.P=0.046\right)$. Most of this could be attributed to whether the sheep had received LPS or saline during the first period (14.63 v. $11.35 \times 10^{9}$ cells $/ 1$ blood, SED $1.487, P=0.055$, respectively). There were no differences between allocated groups (saline or LPS) in leucocyte count before period 1 . There were no period or previous treatment effects on the proportion of neutrophils (34\%) and lymphocytes (64\%) in the monocyte population before each infusion period. At the end of the 20-h infusion, numbers of lymphocyte cells had more than doubled in response to LPS challenge compared with saline infusion (Table 1).

Endotoxaemia tended to cause a $30 \%$ decrease in arterial glucose $(P=0.067)$, whereas lactate concentrations were unaffected (Table 1). Arterial plasma concentrations of both total protein $(-6 \%, P=0.018)$ and albumin $(-4 \%, P=0.007$; Table 1$)$ were reduced by LPS. In contrast, although the FSR of albumin was also decreased $(-48 \%, P<0.001)$, that of total protein was increased $(+37 \%, P=0 \cdot 012$; Table 2$)$. As total plasma volume (average $2 \cdot 18$ litres) was unaffected by either period or treatment, similar directions of change were also observed for the ASR of both albumin and total protein (both $P<0 \cdot 01$; Table 2) in response to LPS. The substantial increase in lymphocyte numbers was accompanied by a $63 \%$ increase in FSR $(P=0.043$; Table 2$)$, whereas the ASR was elevated by $386 \%$ $(P<0 \cdot 001)$. For all these variables, the responses to LPS were independent of whether the supplemental AA were provided or not. Responses reported in both Tables 1 and 2 for the eight sheep with complete functional catheters across splanchnic tissues at the end of the study were similar to data obtained from the original eleven sheep (online Supplementary Tables S1 and S2).

\section{Arterial plasma concentrations of amino acids}

For most non-infused AA, the arterial plasma concentrations were reduced substantially with both LPS and LPS + AA treatments (by 20-50\%,P<0.01; Table 3). The exceptions were 
Table 1. Impact of a 20-h infusion of saline or lipopolysaccharide (LPS; $2 \mathrm{ng} / \mathrm{kg}$ live weight per min), either with or without six supplemental amino acids (AA), on arterial concentrations of albumin, total protein, glucose, lactate and lymphocytes in eight sheep (Predicted means with their standard errors of the difference (SED) between means for the effect of treatment)

\begin{tabular}{|c|c|c|c|c|c|c|c|}
\hline & \multicolumn{3}{|c|}{ Treatment } & \multirow[b]{2}{*}{ SED } & \multicolumn{3}{|c|}{$P$} \\
\hline & Saline & LPS & $\mathrm{LPS}+\mathrm{AA}$ & & Treatment ${ }^{*}$ & Period $^{*}$ & LPS status $†$ \\
\hline Albumin (g/l) & $27 \cdot 3^{\mathrm{a}}$ & $26 \cdot 7^{a, b}$ & $25 \cdot 8^{\mathrm{b}}$ & 0.48 & 0.021 & 0.022 & 0.007 \\
\hline Protein $(\mathrm{g} / \mathrm{l})$ & $62 \cdot 2$ & 59.9 & $58 \cdot 1$ & 1.85 & 0.059 & NS & 0.018 \\
\hline Glucose (mм) & 4.09 & 2.59 & 3.25 & 0.567 & 0.070 & NS & 0.067 \\
\hline Lactate $(\mathrm{mm})$ & 1.42 & $1 \cdot 19$ & 1.56 & 0.566 & NS & NS & NS \\
\hline Lymphocytes $\left(10^{9}\right.$ cells/l)‡ & $4.58^{a}$ & $11.04^{\mathrm{b}}$ & $10 \cdot 74^{\mathrm{b}}$ & $1 \cdot 182$ & 0.002 & NS & $<0.001$ \\
\hline
\end{tabular}

${ }^{\mathrm{a}, \mathrm{b}}$ Mean values within a row with unlike superscript letters were significantly different $(P<0.05)$; post hoc $t$ test was performed to compare the treatment means.

* Analysed by random-effects model, with sheep and period within sheep as random effects and period and treatment plus their interaction as fixed effects, where treatment was either a saline, LPS or LPS + AA infusion. There were no period $\times$ treatment effects $(P>0.05)$.

$\dagger$ Analysed by random-effects model as described above, where treatment reflects LPS status - that is either saline or LPS (both alone and in combination with AA).

‡ One missing value (for LPS treatment).

Table 2. Effect of a 20-h infusion of saline or lipopolysaccharide (LPS; $2 \mathrm{ng} / \mathrm{kg}$ live weight per min), either with or without six supplemental amino acids (AA), on synthesis rates of plasma albumin, total plasma protein and lymphocytes in eight sheep (Predicted means with their standard errors of the difference between means for the effect of treatment)

\begin{tabular}{|c|c|c|c|c|c|c|c|}
\hline & \multicolumn{3}{|c|}{ Treatment } & \multirow[b]{2}{*}{ SED } & \multicolumn{3}{|c|}{$P$} \\
\hline & Saline & LPS & $\mathrm{LPS}+\mathrm{AA}$ & & Treatment ${ }^{*}$ & Period ${ }^{*}$ & LPS status $†$ \\
\hline \multicolumn{8}{|l|}{ Albumin } \\
\hline FSR (\%/d) & $4.88^{\mathrm{a}}$ & $2 \cdot 22^{\mathrm{b}}$ & $2 \cdot 52^{\mathrm{b}}$ & 0.462 & $<0.001$ & NS & $<0.001$ \\
\hline ASR $(g / d)$ & $2 \cdot 92^{\mathrm{a}}$ & $1 \cdot 35^{\mathrm{b}}$ & $1.38^{b}$ & 0.430 & 0.004 & NS & 0.001 \\
\hline \multicolumn{8}{|l|}{ Total protein } \\
\hline FSR $(\% / d)$ & $11 \cdot 4^{\mathrm{a}}$ & $16 \cdot 2^{\mathrm{b}}$ & $15 \cdot 1^{\mathrm{b}}$ & 1.49 & 0.043 & NS & 0.012 \\
\hline ASR $(g / d) \ddagger$ & $15 \cdot 2^{a}$ & $19 \cdot 2^{a, b}$ & $21 \cdot 2^{\mathrm{b}}$ & 1.83 & 0.048 & NS & 0.007 \\
\hline \multicolumn{8}{|l|}{ Lymphocytes } \\
\hline FSR $(\% / d)$ & $6 \cdot 33^{a}$ & $10 \cdot 95^{\mathrm{b}}$ & $9 \cdot 68^{a, b}$ & 1.75 & 0.025 & $0.032 \S$ & $0.043 \S$ \\
\hline ASR $(\mathrm{mg} / \mathrm{d}) \|$ & $25 \cdot 0^{\mathrm{a}}$ & $91 \cdot 2^{\mathrm{b}}$ & $101 \cdot 5^{\mathrm{b}}$ & 19.85 & $<0.001$ & $0.034 \S$ & $<0.001$ \\
\hline
\end{tabular}

FSR, fractional synthesis rate; ASR, absolute synthesis rate.

a,b Mean values within a row with unlike superscript letters were significantly different $(P<0.05)$; post hoc $t$ test was performed to compare the treatment means.

* Analysed by random-effects model, with sheep and period within sheep as random effects and period and treatment plus their interaction as fixed effects, where treatment was either a saline, LPS or LPS + AA infusion.

$†$ Analysed by random-effects model as described above, where treatment reflects LPS status - that is either saline or LPS (both alone and in combination with $\mathrm{AA})$.

$\ddagger$ Period $\times$ treatment effect $(P=0.029)$ values lower during period 2 for LPS treatment (similar between periods for saline and LPS + AA infusions).

$\S$ Values lower during period 2.

II One missing value (LPS).

tryptophan, where only a tendency was observed $(-15 \%$, $P=0.079)$, whereas for phenylalanine the plasma concentration increased $(+30 \%, P<0 \cdot 001)$. The reductions for the non-infused AA were not influenced by the infusion of the six AA. LPS infusion also increased plasma urea $(22 \%, P=0 \cdot 014)$.

For the six AA that formed the supplement, these also showed decreased plasma concentrations when the sheep were challenged with LPS but infused with saline (reduced by $14-74 \%$, all $P<0.05$ ). For the four sheep in which the supplement was infused, this restored plasma concentrations to salineinfused values for cysteine, glutamine, methionine, proline and serine (Table 3). The infusion of threonine over-compensated $(P=0 \cdot 007)$.

\section{Splanchnic bed metabolism}

Plasma flows in the portal vein, hepatic vein and hepatic artery (means $1.347,1.428$ and $0.080 \mathrm{~kg} / \mathrm{min}$, respectively) were not altered by the endotoxin challenge (data not shown), nor were there any effects of LPS (with or without supplemental AA) on splanchnic tissue $\mathrm{O}_{2}$ uptake $(-112$ and $-113 \mu \mathrm{mol} / \mathrm{min}$ for PDV and liver, respectively). Although glucose concentrations were higher in the hepatic vein than in either the portal vein or hepatic artery $(3.81,3.56,3.51 \mathrm{~mm}$, respectively, SED 0.041 , $P<0.001)$ with, in consequence, more glucose appearance across the liver than the PDV $(+360 v++89 \mu \mathrm{mol} / \mathrm{min}$, SED $79 \cdot 1$, $P<0 \cdot 001$ ), there was no effect of LPS infusion, with or without infused AA present. Similarly, lactate transfers were also unaffected by endotoxaemia $(-130$ and $+64 \mu \mathrm{mol} / \mathrm{min}$ for PDV and liver, respectively).

\section{Portal-drained viscera amino acid transfers}

All AA, except glutamine, showed net positive appearances (uptake) across the PDV under the various experimental conditions (Table 4). Over the $4 \mathrm{~h}$ of sampling, infusion of LPS did 
Table 3. Effect of a 20-h infusion of saline or lipopolysaccharide (LPS; $2 \mathrm{ng} / \mathrm{kg}$ live weight per min), either with or without six supplemental amino acids (AA), on plasma arterial concentrations $(\mu \mathrm{mol} / \mathrm{kg})$ of AA in eight sheep (Predicted means with their standard errors of the difference between means for the effect of treatment)

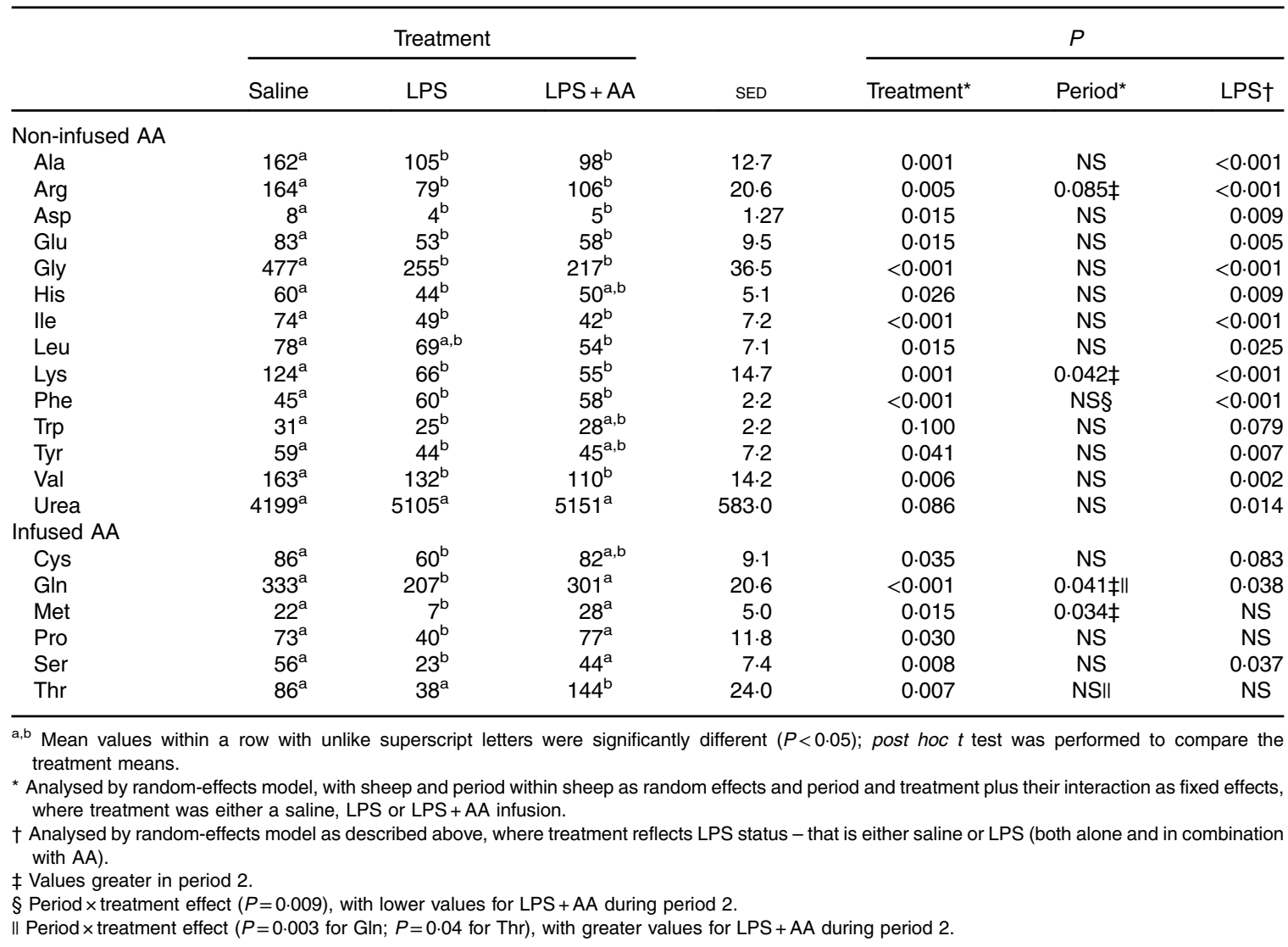

not alter net PDV appearance, compatible with the lack of effect of the endotoxin on food intake. In contrast, the net PDV appearance of glutamine across the PDV was negative during saline infusions (indicative of metabolism of endogenous glutamine by the gut tissues), but this was reduced by $67 \%$ $(P=0.014)$ with LPS infusion (without supplemental AA). Neither removal of urea nor appearance of ammonia across the PDV was affected by LPS infusion. As expected, mesenteric vein infusion of the six AA increased their portal vein appearance (all $P<0.001$ ). For the six infused AA, apparent recovery within sheep across the PDV was not significantly different from $100 \%$ for methionine, proline, serine, threonine and glutamine, but only $71 \%$ for cysteine $(P=0.004)$. The amount of glutamine infused was sufficient to provide a net positive supply to the liver (Table 4). PDV appearances of alanine and lysine (both $P<0.05)$ were also increased by infusion of the AA supplement. For alanine, this restored values to those of the saline-infused period, whereas for arginine net supply increased above that for the control (saline) period $(P=0.012)$.

\section{Hepatic amino acid transfers}

Except for glutamine and glutamate, during saline infusion there was net removal of each AA across the liver and these were different from zero $(P<0.05)$, except for aspartate and cysteine. During saline infusion, there was net hepatic export of glutamate $(P<0 \cdot 001)$. LPS infusion (without supplemental AA) increased net hepatic removal $(P<0.05)$ of six AA (Table 5$)$, and these contributed to the $75 \%$ extra extraction of total AA-N $(P=0.012)$. For the non-infused AA, hepatic removal was not affected by the supplemental AA in the presence of LPS (Table 5). In contrast, extraction by the liver of all the infused AA was markedly increased $(P<0 \cdot 01)$, and this resulted in an additional $40 \%$ removal of total AA-N $(P=0.030)$.

\section{Net splanchnic amino acid transfers}

The difference between net absorption (plus any infused AA) and hepatic removal represents net splanchnic flow to peripheral tissues (Table 6). With saline infusion, only glycine and glutamine had significant $(P<0.05)$ negative net transfers that is hepatic uptake exceeded PDV absorption, and thus additional amounts were removed from the peripheral circulation. In terms of positive net post-splanchnic supply, most AA had values that were significantly different from 0 $(P<0.05)$; the exceptions were alanine, cysteine, histidine, phenylalanine, tryptophan and tyrosine. In response to LPS alone, net splanchnic supply decreased for alanine and arginine $(P<0.05)$. Provision of supplemental AA increased net splanchnic supply for cysteine, methionine, proline, threonine (all $P<0.010)$ and serine $(P=0.037)$, but not glutamine.

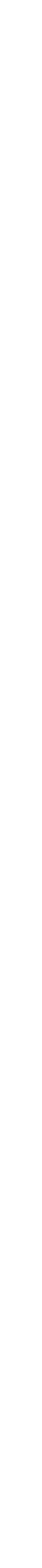


Table 4. Net portal-drained viscera supply (absorbed from diet + any infused amino acid (AA)) of AA-N ( $\mu \mathrm{mol} \mathrm{N} / \mathrm{min}$ ) in eight sheep in response to 20 -h infusions of saline or lipopolysaccharide (LPS; $2 \mathrm{ng} / \mathrm{kg}$ live weight per min), either with or without six supplemental AA (Predicted means with their standard errors of the difference between means for the effect of treatment)

\begin{tabular}{|c|c|c|c|c|c|c|c|}
\hline & \multicolumn{3}{|c|}{ Treatment } & \multirow[b]{2}{*}{ SED } & \multicolumn{3}{|c|}{$P$} \\
\hline & Saline & LPS & $\mathrm{LPS}+\mathrm{AA}$ & & Treatment ${ }^{\star}$ & Period $^{*}$ & LPS† \\
\hline \multicolumn{8}{|c|}{ Non-infused AA-N } \\
\hline Ala & $31 \cdot 3^{\mathrm{a}, \mathrm{b}}$ & $24 \cdot 0$ & $39.9^{c}$ & 3.06 & 0.015 & NS & NS \\
\hline Arg & $34 \cdot 2^{\mathrm{a}}$ & $19 \cdot 6^{\mathrm{b}}$ & $60 \cdot 2^{\mathrm{c}}$ & 4.32 & 0.006 & $0.017 \ddagger$ & NS \\
\hline Asp & 4.3 & 3.4 & 3.5 & 1.50 & NS§ & NS & NS \\
\hline Glu & $5 \cdot 1$ & 14.8 & $13 \cdot 0$ & 5.03 & NS & NS & 0.083 \\
\hline Gly & $20 \cdot 0$ & $18 \cdot 1$ & $25 \cdot 2$ & 2.68 & NS & NS & NS \\
\hline His & $18 \cdot 6$ & $15 \cdot 0$ & $19 \cdot 0$ & 2.58 & NS & NS & NS \\
\hline Ile & $15 \cdot 5$ & $12 \cdot 3$ & $17 \cdot 3$ & $2 \cdot 28$ & NS & $0.053 \ddagger$ & NS \\
\hline Leu & $19 \cdot 1$ & $15 \cdot 0$ & $22 \cdot 9$ & $2 \cdot 60$ & 0.079 & NS & NS \\
\hline Lys\|lI & $40 \cdot 6^{a}$ & $30 \cdot 3^{\mathrm{b}}$ & $51 \cdot 3^{\mathrm{c}}$ & 4.43 & 0.021 & $0.034 \ddagger$ & NS \\
\hline Phe & $12 \cdot 3$ & 9.7 & 13.8 & 1.36 & 0.075 & $0.062 \ddagger$ & NS \\
\hline $\operatorname{Trp}$ & 3.7 & 2.5 & $6 \cdot 0$ & 1.57 & NS & $0.093 \ddagger$ & NS \\
\hline Tyr & $10 \cdot 5$ & 7.9 & $12 \cdot 2$ & 1.41 & 0.084 & $0.069 \ddagger$ & NS \\
\hline Val & 17.4 & 13.4 & $19 \cdot 3$ & 2.58 & NS & NS & NS \\
\hline Urea-N & -259 & -359 & -329 & 101.5 & NS & NS & NS \\
\hline Ammonia & 547 & 433 & 807 & 139.3 & 0.083 & NS & NS \\
\hline \multicolumn{8}{|c|}{ Infused AA-NII } \\
\hline Cys & $1.9^{\mathrm{a}}$ & $1.8^{\mathrm{a}}$ & $15 \cdot 5^{\mathrm{b}}$ & 0.79 & $<0.001$ & NS & 0.052 \\
\hline Gln & $-51 \cdot 6^{a}$ & $-17 \cdot 6^{\mathrm{b}}$ & $27 \cdot 4^{\mathrm{c}}$ & 11.59 & $<0.001$ & NS & 0.002 \\
\hline Met & $6 \cdot 4^{a}$ & $6 \cdot 2^{\mathrm{a}}$ & $17 \cdot 7^{\mathrm{b}}$ & 1.09 & $<0.001$ & NS & 0.071 \\
\hline Pro & $10.9^{\mathrm{a}}$ & $10 \cdot 2^{\mathrm{a}}$ & $26 \cdot 0^{\mathrm{b}}$ & 1.95 & $<0.001$ & NS & NS \\
\hline Ser & $24 \cdot 1^{a}$ & $21 \cdot 0^{\mathrm{a}}$ & $55 \cdot 0^{\mathrm{b}}$ & 4.62 & $<0.001$ & NS & NS \\
\hline Thr & $13 \cdot 8^{\mathrm{a}}$ & $12 \cdot 2^{\mathrm{a}}$ & $46 \cdot 7^{\mathrm{b}}$ & 2.73 & $<0.001$ & NS & 0.099 \\
\hline
\end{tabular}

a,b,c Mean values within a row with unlike superscript letters were significantly different $(P<0.05)$; post hoc $t$ test was performed to compare the treatment means.

* Analysed by random effects model, with sheep and period within sheep as random effects and period and treatment plus their interaction as fixed effects, where treatment was either a saline, LPS or LPS + AA infusion. There were no period $\times$ treatment effects $(P>0.05)$.

† Analysed by random-effects model as described above, where treatment reflects LPS status - that is either saline or LPS (both alone and in combination with $A$ A).

$\ddagger$ Values lower for period 1 than period 2, except for Arg where period 1 was greater.

$\S$ Only three sheep for the LPS + AA treatment.

II Infusion rates ( $\mu \mathrm{mol}-\mathrm{N} / \mathrm{min}$ ) into mesenteric vein, 17.8 (Pro), 10.8 (Met), 34.7 (Ser), 38.4 (Thr), 19.2 (Cys), 89.2 (Gln) for LPS + AA treatment.

\section{Isotope transfers}

Phenylalanine whole-body ILR was increased in response to LPS infusion, both with and without the AA supplement (mean $17 \%, P<0.001$; Table 7 ). Endotoxaemia did not alter ILR across the PDV, regardless of whether the arterial or venous plasma enrichment was chosen as precursor (latter data not shown). In contrast, with either method of calculation, both liver $(P=0.023)$ and total splanchnic $(P=0.034)$ metabolism was increased by LPS. In combination, LPS plus supplemental AA increased hepatic protein synthesis by $12 \%(P=0.036)$ compared with LPS alone. Together, the hepatic and PDV response accounted for approximately $40 \%$ of whole-body ILR under both saline and LPS infusions, but with the contribution from the liver more than 2-fold that from the PDV.

\section{Discussion}

Although experimentally induced endotoxaemia has been proven to be a popular research tool to study the metabolic events and beneficial nutrition interventions related to inflammation, the responses observed can vary because of many factors, including species, severity of dose and period of measurement. For example, in both pigs ${ }^{(4)}$ and sheep ${ }^{(3)}$, LPS causes a decrease in plasma concentration for most AA. In contrast, in rodents, concentrations can increase ${ }^{(26)}$, whereas in humans both null ${ }^{(27)}$ or decreased ${ }^{(28)}$ responses have been reported. The dose used in the current study is below that usually adopted - for example only $4 \%$ of the hourly dose used in pigs ${ }^{(4)}$ - but it does give the advantage that pyrexia and anorexia responses are mild and of limited duration yet with similar responses in arterial AA concentrations and metabolic flows ${ }^{(3)}$.

\section{Whole-body and splanchnic tissue response to endotoxin challenge}

The LPS dose increased whole-body ILR of plasma phenylalanine in the sheep, as observed previously ${ }^{(3)}$, in support of observations in pigs ${ }^{(1)}$ and humans ${ }^{(27)}$. Similarly, the increase in lymphocyte cell numbers is in agreement with other findings during infection and inflammation challenges ${ }^{(3,29)}$, although in shorter-term endotoxaemia studies $(<2.5 \mathrm{~h})$ in human such changes are not observed ${ }^{(30)}$. Increased cell numbers may involve mobilisation of lymphocytes from pre-existing stores and/or a higher fractional rate of synthesis, and the current data confirm that the latter occurred. Nonetheless, the 4-fold increase in total protein synthesis of lymphocytes represented 
Table 5. Net hepatic removals ( $\mu \mathrm{mol} \mathrm{N} / \mathrm{min}$ ) of amino acid (AA)-N in eight sheep in response to 20-h infusions of saline or lipopolysaccharide (LPS; $2 \mathrm{ng} / \mathrm{kg}$ live weight per $\mathrm{min}$ ), either with or without six supplemental AA (Predicted means with their standard errors of the difference between means for the effect of treatment)

\begin{tabular}{|c|c|c|c|c|c|c|c|}
\hline & \multicolumn{3}{|c|}{ Treatment } & \multirow[b]{2}{*}{ SED } & \multicolumn{3}{|c|}{$P$} \\
\hline & Saline & LPS & $\mathrm{LPS}+\mathrm{AA}$ & & Treatment ${ }^{\star}$ & Period $^{*}$ & LPS† \\
\hline \multicolumn{8}{|c|}{ Non-infused AA-N } \\
\hline Ala & $-24 \cdot 8^{a}$ & $-35 \cdot 6^{\mathrm{b}}$ & $-36 \cdot 7^{b}$ & 5.05 & 0.028 & 0.052 & 0.004 \\
\hline Arg & $-25 \cdot 9^{a}$ & $-42 \cdot 9^{\mathrm{a}, \mathrm{b}}$ & $-60 \cdot 6^{b}$ & 9.51 & $0.032 \ddagger$ & NS & 0.031 \\
\hline Asp & -0.6 & $-2 \cdot 0$ & $-1 \cdot 2$ & 1.08 & NS & NS§ & NS \\
\hline Glu & $16 \cdot 8$ & $6 \cdot 4$ & $-4 \cdot 7$ & $6 \cdot 70$ & NS & NS & NS \\
\hline Gly & -30.5 & -38.1 & $-35 \cdot 8$ & $5 \cdot 18$ & NS & NS & NS \\
\hline His & $-18 \cdot 9$ & $-21 \cdot 8$ & $-20 \cdot 8$ & 2.06 & NS & $0.020 \|$ & 0.058 \\
\hline Ile & $-2 \cdot 6$ & -4.9 & $-5 \cdot 3$ & 0.96 & 0.074 & NS§ & 0.036 \\
\hline Leu & $-5 \cdot 1^{\mathrm{a}}$ & $-8.0^{\mathrm{b}}$ & $-8 \cdot 0^{\mathrm{b}}$ & 0.96 & 0.009 & $0.020 \S \|$ & 0.008 \\
\hline Lys & $-12 \cdot 9^{a}$ & $-18 \cdot 7^{b}$ & $-24 \cdot 3^{\mathrm{b}}$ & $2 \cdot 61$ & 0.004 & $0.099 \S$ & 0.009 \\
\hline Phe & $-10 \cdot 9$ & $-12 \cdot 5$ & $-13 \cdot 3$ & 1.39 & NS & NS & 0.029 \\
\hline Trp & -3.5 & -3.6 & $-8 \cdot 3$ & 1.93 & 0.052 & NS & NS \\
\hline Tyr & -9.6 & -9.6 & -9.4 & 1.19 & NS & NS§ & NS \\
\hline Val & $-4 \cdot 0$ & $-5 \cdot 6$ & 0.2 & 3.44 & NS & NS & NS \\
\hline Urea & 658 & 614 & 802 & $161 \cdot 1$ & NS & NS & NS \\
\hline Ammonia & -579 & -456 & -824 & $138 \cdot 7$ & 0.088 & NS & NS \\
\hline \multicolumn{8}{|l|}{ Infused AA-N } \\
\hline Cys & $-0.8^{\mathrm{a}}$ & $-1.8^{\mathrm{a}}$ & $-8 \cdot 7^{\mathrm{b}}$ & 0.70 & $<0.001$ & NS & 0.017 \\
\hline Gln & $3 \cdot 8^{a}$ & $-38.5^{\mathrm{b}}$ & $-78 \cdot 2^{c}$ & 18.6 & 0.004 & NS & 0.003 \\
\hline Met & $-3 \cdot 6^{\mathrm{a}}$ & $-4 \cdot 4^{a}$ & $-11.5^{\mathrm{b}}$ & 1.73 & $<0.001$ & NS & 0.067 \\
\hline Pro & $-5 \cdot 8^{a}$ & $-8 \cdot 8^{\mathrm{b}}$ & $-14 \cdot 2^{\mathrm{C}}$ & 1.05 & $<0.001$ & $0.014 \S$ & 0.005 \\
\hline Ser & $-12 \cdot 7^{a}$ & $-15 \cdot 3^{a}$ & $-37 \cdot 1^{\mathrm{b}}$ & 3.12 & $<0.001$ & NS & 0.034 \\
\hline Thr & $-5 \cdot 5^{\mathrm{a}}$ & $-6 \cdot 9^{b}$ & $-32 \cdot 0^{\mathrm{c}}$ & 0.90 & $<0.001$ & NS & 0.036 \\
\hline Total AA-N & $-154^{a}$ & $-271^{\mathrm{b}}$ & $-382^{c}$ & 38.4 & $<0.001$ & NS & 0.001 \\
\hline \multicolumn{8}{|c|}{$\begin{array}{l}\text { a,b,c Mean values within a row with unlike superscript letters were significantly different }(P<0.05) \text {; post hoc } t \text { test was performed to compare the } \\
\text { treatment means. } \\
\text { * Analysed by random-effects model, with sheep and period within sheep as random effects and period and treatment plus their interaction as fixed effects } \\
\text { where treatment was either a saline, LPS or LPS }+ \text { AA infusion. } \\
\text { † Analysed by random-effects model as described above, where treatment reflects LPS status - that is either saline or LPS (both alone and in combination } \\
\text { with AA). } \\
\text { † Only three sheep for the LPS }+ \text { AA treatment. } \\
\text { § Period } \times \text { treatment interaction }(P<0.05) \text { with less uptake during period } 2 \text { for LPS and LPS + AA. } \\
\text { II More hepatic removal during period } 1 \text {. }\end{array}$} \\
\hline
\end{tabular}

$<0.1 \%$ of whole-body protein synthesis and would only require $<0.2 \%$ of the phenylalanine absorbed from the diet. In contrast, the net increase in total plasma protein synthesis $(4 \mathrm{~g} / \mathrm{d}$, from Table 2) would require an additional $5 \%$ of the absorbed phenylalanine. The latter value compares with estimates for the total immune system of approximately $8 \%$ in humans ${ }^{(31)}$ and with nutritional costs increased from 1.2 to $6.7 \%$ between saline-infused and LPS-challenged chicks ${ }^{(32)}$. Other components of the immune system, which are not monitored in the current study and including the thymus, spleen, bone marrow and immune cells, may also be activated ${ }^{(33)}$ with a possible greater contribution from secondary lymphoid organs compared with primary tissues plus blood lymphocytes ${ }^{(29)}$.

Although endotoxaemia is associated with changes in NO status $^{(26)}$, blood (and plasma) flows across the splanchnic tissues remained unaltered. Again, this is in line with observations in both pigs ${ }^{(4,26)}$ and rodents ${ }^{(26)}$. In humans, a near doubling of splanchnic blood flow was observed ${ }^{(27)}$, but this had disappeared $6 \mathrm{~h}$ after the bolus injection of endotoxin. LPS also exerts direct effects on the gut, with consequent damage ${ }^{(34)}$ and altered permeability ${ }^{(15)}$. It is clear, however, that there was no impact on net absorption of most AA in the current experiment, but this may relate to the parenteral route of LPS infusion and the low dose used. Therefore, the altered arterial AA concentrations must be a consequence of altered post-intestinal tract metabolism. This contrasts with pigs, in which, following a more severe endotoxin challenge supplied enterally, increases in net portal vein appearance for several AA were approximately double compared with that supplied from the diet, suggestive of mobilisation of intestinal tissue ${ }^{(4)}$.

In the current study, glutamine showed lowered net removal in response to LPS. This has similarities to observations both in pigs post surgery ${ }^{(35)}$ and in tumour-bearing rats ${ }^{(17)}$, in which the gut consumed less glutamine, possibly in response to lowered arterial concentrations. Indeed, arterial glutamine, and thus systemic supply, was reduced by $38 \%$ in the current study.

Under control conditions, hepatic AA removal followed patterns previously reported ${ }^{(36,37)}$, with most of the net absorbed histidine and phenylalanine extracted, but with only limited uptake of the branched-chain AA (17-27\%). There was net output of glutamate, but, contrary to earlier observations, this was not balanced by similar net hepatic glutamine removal $^{(23,38)}$. More $\mathrm{N}$ was extracted from plasma by the liver as combined AA-N and ammonia-N than was released as urea-N, compatible with hepatic needs to support other processes ${ }^{(23)}$, including the synthesis of constitutive and export proteins. Part of the difference $(4.5 \mathrm{mmol} / \mathrm{h})$ would be used to support the measured albumin synthesis $(1.4 \mathrm{mmol}-\mathrm{N} / \mathrm{h})$, but it would be 
Table 6. Net total splanchnic appearances ( $\mu \mathrm{mol} \mathrm{N} / \mathrm{min}$ ) of amino acid (AA)-N in response to a 20-h infusion of saline or lipopolysaccharide (LPS; 2 ng/kg live weight per min), either with or without six supplemental AA, LPS, in eight sheep (Predicted means with their standard errors of the difference between means for the effect of treatment)

\begin{tabular}{|c|c|c|c|c|c|c|c|}
\hline & \multicolumn{3}{|c|}{ Treatment } & \multirow[b]{2}{*}{ SED } & \multicolumn{3}{|c|}{$P$} \\
\hline & Saline & LPS & LPS + AA & & Treatment* $^{\star}$ & Period* $^{\star}$ & LPS† \\
\hline \multicolumn{8}{|c|}{ Non-infused AA-N } \\
\hline Ala & $6 \cdot 5^{a}$ & $-11.9^{b}$ & $3 \cdot 6^{\mathrm{a}}$ & 3.93 & 0.006 & $0.005 \ddagger$ & 0.030 \\
\hline Arg & $8 \cdot 4^{\mathrm{a}}$ & $-20 \cdot 4^{b}$ & $-2 \cdot 9^{a, b}$ & $10 \cdot 01$ & $0.048 \S$ & NS & 0.043 \\
\hline Asp & 3.7 & 1.5 & $2 \cdot 2$ & 1.09 & 0.084 & 0.060 & 0.013 \\
\hline Glu & 21.9 & $20 \cdot 4$ & $18 \cdot 5$ & 9.09 & NS & NS & NS \\
\hline Gly & $-10 \cdot 6$ & $-15 \cdot 8$ & $-14 \cdot 7$ & 5.65 & NS & NS & NS \\
\hline His & -0.3 & $-3 \cdot 1$ & $-5 \cdot 4$ & 2.85 & NS & 0.070 & 0.083 \\
\hline Ile & 12.9 & $8 \cdot 1$ & $11 \cdot 3$ & $3 \cdot 17$ & NS & 0.060 & 0.099 \\
\hline Leu & $14 \cdot 0$ & $7 \cdot 5$ & $14 \cdot 3$ & $2 \cdot 64$ & 0.054 & $0.026 \ddagger$ & NS \\
\hline Lys & $27 \cdot 8$ & 14.0 & $24 \cdot 7$ & 5.90 & 0.077 & $0.044 \ddagger$ & 0.097 \\
\hline Phe & 1.5 & $-2 \cdot 1$ & -0.2 & 1.34 & 0.059 & 0.059 & 0.071 \\
\hline Try & $0 \cdot 1^{a}$ & $-1 \cdot 1^{a, b}$ & $-2 \cdot 3^{\mathrm{b}}$ & 0.67 & 0.010 & NS & 0.024 \\
\hline Tyr & 0.9 & $-1 \cdot 2$ & $2 \cdot 3$ & $1 \cdot 22$ & 0.073 & $0.022 \ddagger$ & NS \\
\hline Val & 13.5 & 8.0 & $19 \cdot 3$ & $4 \cdot 27$ & 0.096 & 0.066 & NS \\
\hline Urea-N & 399 & 288 & 440 & $144 \cdot 7$ & NS & NS & NS \\
\hline Ammonia & -32 & -22 & 18 & $14 \cdot 7$ & NS & NSII & NS \\
\hline \multicolumn{8}{|l|}{ Infused AA-N } \\
\hline Cys & $1 \cdot 1^{\mathrm{a}}$ & $0.2^{a}$ & $6 \cdot 6^{\mathrm{b}}$ & 1.05 & 0.001 & NS & NS \\
\hline Gln & $-47 \cdot 9$ & -53.0 & -53.9 & $25 \cdot 55$ & NS & NS & NS \\
\hline Met & $2 \cdot 8^{a}$ & $2 \cdot 1^{\mathrm{a}}$ & $5 \cdot 8^{\mathrm{b}}$ & 0.082 & 0.006 & $0.070 \|$ & NS \\
\hline Pro & $5 \cdot 1^{a}$ & $1 \cdot 2^{\mathrm{a}}$ & $11.9^{b}$ & 1.89 & 0.004 & $0.026 \ddagger$ & NS \\
\hline Ser & 11.4 & $6 \cdot 0$ & $17 \cdot 0$ & 3.94 & 0.081 & 0.088 & NS \\
\hline Thr & $8 \cdot 3^{a}$ & $4 \cdot 8^{a}$ & $15 \cdot 2^{b}$ & 2.57 & 0.004 & NS & NS \\
\hline Net AA-N & $79^{a}$ & $-22^{\mathrm{b}}$ & $63^{a, b}$ & $36 \cdot 9$ & 0.069 & $0.028 \mp$ & NS \\
\hline
\end{tabular}

TSP total splanchnic release.

a,b Mean values within a row with unlike superscript letters were significantly different $(P<0.05)$; post hoc $t$ test was performed to compare the treatment means.

* Analysed by random effects model, with sheep and period within sheep as random effects and period and treatment plus their interaction as fixed effects, where treatment was either a saline, LPS or LPS + AA infusion.

† Analysed by random-effects model as described above, where treatment reflects LPS status - that is either saline or LPS (both alone and in combination with AA).

$\ddagger$ Values lower for period 1 than period 2 .

$\S$ Only three sheep for the LPS + AA treatment.

$\|$ Period $\times$ treatment interaction for Met with lower TSP $(P=0.014)$ during period 2 for saline infusion, whereas values for LPS and LPS + AA infusions were greater.

Table 7. Impact of saline or lipopolysaccharide (LPS; $2 \mathrm{ng} / \mathrm{kg}$ live weight per min), either with or without six supplemental amino acids (AA), on ILR ( $\mathrm{mmol} / \mathrm{h}$ ) of plasma phenylalanine for the whole body (WB) and across the tissues of the splanchnic bed (Predicted means with their standard errors of the difference between means for the effect of treatment)

\begin{tabular}{|c|c|c|c|c|c|c|c|}
\hline & \multicolumn{3}{|c|}{ Treatment ${ }^{\star}$} & \multirow[b]{2}{*}{ SED } & \multicolumn{3}{|c|}{$P$} \\
\hline & Saline & LPS & $\mathrm{LPS}+\mathrm{AA}$ & & Treatment† & Period $†$ & LPS $\ddagger$ \\
\hline WB & $2 \cdot 28^{a}$ & $2 \cdot 58^{\mathrm{b}}$ & $2 \cdot 74^{\mathrm{b}}$ & 0.097 & 0.003 & $0.096 \S$ & $<0.001$ \\
\hline \multicolumn{8}{|c|}{ Splanchnic tissues } \\
\hline PDV & -0.31 & -0.35 & -0.34 & 0.101 & NS & $0.047 \|$ & NS \\
\hline Liver & $-0.57^{\mathrm{a}}$ & $-0.72^{a, b}$ & $-0.83^{b}$ & 0.111 & 0.046 & NS & 0.023 \\
\hline TSP & -0.87 & -1.09 & $-1 \cdot 15$ & 0.167 & NS & NS & 0.034 \\
\hline \multicolumn{8}{|c|}{ Tissue:WB ratio } \\
\hline PDV & 0.13 & 0.13 & 0.13 & 0.029 & NS & $0.072 \|$ & NS \\
\hline Liver & 0.25 & 0.28 & 0.30 & 0.053 & NS & NS & NS \\
\hline TSP & 0.39 & 0.43 & 0.42 & 0.076 & NS & NS & NS \\
\hline
\end{tabular}

PDV, portal-drained viscera (total gut); TSP, total splanchnic preparation (liver + PDV).

a,b Mean values within a row with unlike superscript letters were significantly different $(P<0.05)$; post hoc $t$ test was performed to compare the treatment means.

* All values based on arterial enrichments.

$\dagger$ Analysed by random-effects model, with sheep and period within sheep as random effects and period and treatment plus their interaction as fixed effects, where treatment was either a saline, LPS or LPS + AA infusion. There were no period $x$ treatment effects $(P>0.05)$.

$\ddagger$ Analysed by random-effects model as described above, where treatment reflects LPS status - that is either saline or LPS (both alone and in combination with $A$ A).

$\S$ Values greater for period 1 than period 2.

II Values greater for period 2 than period 1. 
insufficient to account for estimated total plasma protein synthesis $(7.2 \mathrm{mmol}-\mathrm{N} / \mathrm{h})$, although not all plasma proteins are synthesised by the liver (e.g. globulins).

LPS infusion increased hepatic removal for several AA, including glutamine, leucine, lysine, proline and threonine, and these contributed to the additional $6.5 \mathrm{mmol}$ AA-N/h net removal by the liver, similar to the $8.3 \mathrm{mmol}-\mathrm{N} / \mathrm{h}$ estimated from the change in total liver ILR (from Table 7). How much of this additional uptake of AA-N is catabolised is unclear, because the numerical change in arterial urea was not supported by increased hepatic ureagenesis. Studies in humans have reported increased AA catabolism due to LPS, including hepatic oxidation of leucine ${ }^{(27)}$, greater fractional extraction of leucine across the splanchnic bed during sepsis ${ }^{(39)}$ and elevated whole-body conversion of phenylalanine to tyrosine $e^{(40)}$, primarily a liver event. In addition, infection or inflammation stimulate the synthesis of constitutive and/or export proteins ${ }^{(1,4,33,41)}$.

Phenylalanine is unusual in that the arterial concentration increases during endotoxaemia in pigs ${ }^{(4)}$ and sheep ${ }^{(3)}$, although not in humans ${ }^{(27,28)}$. Hepatic removal of phenylalanine remained unchanged by LPS treatment even though it has been suggested that liver demands for phenylalanine (and tryptophan) would increase during infection and inflammation because of their relatively high abundance in positive acutephase proteins ${ }^{(7)}$, the synthesis of which is increased by infection $^{(42)}$. In the current study, such demands would be offset by simultaneous decreased synthesis $(-50 \%)$ of albumin, a negative acute phase protein that contains $6 \%(\mathrm{w} / \mathrm{w})$ phenylalanine. Therefore, the increased arterial plasma phenylalanine probably relates to mobilisation of protein from non-splanchnic tissues, particularly skeletal muscle ${ }^{(1,43)}$.

\section{Effect of amino acid supplementation}

Targeted supply of nutrients in response to specific physiological, developmental or environmental events is a key nutritional aim. In various clinical situations, much attention has been focused on demands for specific AA. For example, supplementation with large amounts of glutamine has been proposed for a variety of surgical and clinical states ${ }^{(16,44-46)}$ associated with specific needs for the immune system ${ }^{(47)}$. In addition, claims as effective therapies have been made for a number of other AA supplied alone ${ }^{(48-50)}$. Other benefits have involved $\mathrm{AA}$ in combination ${ }^{(13,14)}$, although these have not always been successful ${ }^{(51)}$.

A recent approach involved dynamic measurements in sheep subjected to an LPS challenge in order to quantify the demands for specific $\mathrm{AA}^{(3)}$, and these findings were applied within the current protocol. The success of such an approach can be assessed at several levels. The simplest involves the effect of supplementation on plasma AA concentrations, and this produced statistical restoration to the saline-infused values for five of the AA, although further numerical improvement would be preferred for cysteine and serine. In contrast, threonine was probably over-supplied based on previous sheep data ${ }^{(3)}$, and there may be differences between studies in the sensitivity of the animals to the LPS dose. Notably, LPS caused an $80 \%$ reduction in plasma threonine in the earlier study ${ }^{(3)}$, whereas for the current animals the decrease was only 56\%; therefore, an amount less than that actually given might have been needed to restore to control values. Recovery of AA infused into the post-absorptive venous drainage was not different from unity, except in the case of cysteine, possibly because of the requirement for synthesis of taurine and glutathione - processes that occur within the intestinal cells ${ }^{(52,53)}$

On the basis of the hypothesis that AA are mobilised from tissue protein - particularly muscle ${ }^{(43,54)}$ - to combat inflammation, if one (or more) of these AA are needed in considerable amounts then this will leave the remainder that are released in excess to requirements for protein synthesis. These will then be removed from the body via ureagenesis and lead to depletion of plasma concentrations. If the supplement contains those AA that are needed to support the anti-inflammatory responses, then this should reduce the need for peripheral tissue mobilisation and lower the overall hepatic removal for catabolic purposes. Despite the reasonable success in restoring the plasma concentrations of the supplemented AA to normal, there was no improvement in the plasma concentrations of the nonsupplemented AA and neither was there a reduction in their removal by the liver between the LPS and LPS + AA treatments. For the supplemented AA, only for glutamine was there complete removal of the extra provided. This suggests that the increased arterial glutamine concentrations are probably because of mobilisation from other tissues; muscle is an obvious candidate in which millimolar quantities of free glutamine are present ${ }^{(55)}$ and which is released during severe illness, even in the presence of supplemental glutamine ${ }^{(56)}$. For the other supplemented AA, hepatic removal ranged from $55 \%$ (proline) to $84 \%$ (serine), so the fates were partitioned between increased post-hepatic delivery, which is necessary to restore arterial concentrations to, or above, normal and potential support of liver-based mechanisms. The latter did not, however, involve restoration of the synthesis of the negative acute-phase protein, albumin. This non-response was despite the fact that the increased hepatic uptake of the supplemented AA would, in theory, have the potential to support $30-130 \mathrm{~g} / \mathrm{d}$ of albumin synthesis, in considerable excess of the $1 \mathrm{~g} / \mathrm{d}$ decrease observed. Similarly, the additional AA supplement did not alter rates of synthesis of lymphocytes. These observations might suggest that either other AA are needed in the supplement or that the immediate events during inflammation are less responsive to supplementation, for example there is a metabolic 'over-ride', and perhaps the focus should be on longer-term responses and enhanced recovery, as has been shown to occur in rats treated with exotoxin and supplemented with $\mathrm{AA}^{(14)}$.

In summary, infusion of six AA predicted as key requirements during the response to an LPS challenge restored or exceed arterial concentrations of these to control values but not any of the other non-infused AA. Similarly, there was no restoration of the synthesis of the negative acute-phase protein, albumin, and no change in the elevated protein synthesis of lymphocytes. The parenteral infusion of the low dose of LPS did not affect gut metabolism or net AA absorption except for glutamine, where net removal was reduced. Hepatic uptake of leucine, lysine, glutamine and serine was increased by LPS, with liver removal 
of the latter two plus the other four infused AA increased during the AA supplementation. The data suggest that AA supplementation does not mitigate certain metabolic demands during the acute phase of an endotoxin challenge, but whether supplementation provides benefits on later responses and the period of recovery requires further investigation.

\section{Acknowledgements}

The expertise of A. Graham Calder and Susan Anderson for the various stable isotope analyses is gratefully recognised. Ngaire Dennison is also thanked for her surgical expertise with the trans-splanchnic tissue catheter preparations.

This study was supported by funds provided to the Rowett Institute of Nutrition and Health, University of Aberdeen and Biomathematics and Statistics Scotland by the Rural and Environment Science and Analytical Services Division of the Scottish Government. S. O. H. was a recipient of a FoRST (NZ) award to study abroad.

The contributions of the authors were as follows: C. J. M. N., S. O. H., G. H. and G. E. L. were responsible for the study concept and design. C. J. M. N., S. O. H., G. E. L. and D. M. B. were responsible for data collection and collation. G. E. L. and G. H. were responsible for data analysis and statistical matters. C. J. M. N., S. O.H., G. E. L. and G. H. were responsible for the first draft and critical revision of the manuscript for important intellectual content.

The authors declare that there are no conflicts of interest.

\section{Supplementary material}

For supplementary material/s referred to in this article, please visit http://dx.doi.org/doi:10.1017/S0007114516001860

\section{References}

1. Bruins MJ, Soeters PB, Lamers WH, et al. (2002) L-arginine supplementation in pigs decreases liver protein turnover and increases hindquarter protein turnover both during and after endotoxemia. Am J Clin Nutr 75, 1031-1044.

2. Le Floc'h N, Deblanc C, Cariolet R, et al. (2014) Effect of feed restriction on performance and postprandial nutrient metabolism in pigs co-infected with Mycoplasma hyopneumoniae and swine influenza virus. PLOS ONE 9, e104605.

3. Hoskin SO, Bremner DM, Holtrop G, et al. (2016) Responses in whole-body amino acid kinetics to an acute, sub-clinical endotoxin challenge in lambs. Br J Nutr 115, 576-584.

4. Bruins MJ, Soeters PB \& Deutz NE (2000) Endotoxemia affects organ protein metabolism differently during prolonged feeding in pigs. $J$ Nutr 130, 3003-3013

5. Faure M, Moennoz D, Montigon F, et al. (2003) Mucin production and composition is altered in dextran sulfate sodiuminduced colitis in rats. Dig Dis Sci 48, 1366-1373.

6. Yu F, Bruce LA, Calder AG, et al. (2000) Subclinical infection with the nematode Trichostrongylus colubriformis increases gastrointestinal tract leucine metabolism and reduces availability of leucine for other tissues. J Anim Sci 78, 380-390.

7. Reeds PJ, Fjeld CR \& Jahoor F (1994) Do the differences between the amino acid compositions of acute-phase and muscle proteins have a bearing on nitrogen loss in traumatic states? J Nutr 124, 906-910.

8. Shaw JH \& Wolfe RR (1986) Glucose, fatty acid, and urea kinetics in patients with severe pancreatitis. The response to substrate infusion and total parenteral nutrition. Ann Surg 204, 665-672.

9. Malmezat T, Breuille D, Pouyet C, et al. (2000) Methionine transsulfuration is increased during sepsis in rats. Am J Physiol Endocrinol Metab 279, E1391-E1397.

10. Essen P, McNurlan MA, Thorell A, et al. (1996) Determination of protein synthesis in lymphocytes in vivo after surgery. Clin Sci (Lond) 91, 99-106.

11. Stoll B, Gerok W, Lang F, et al. (1992) Liver cell volume and protein synthesis. Biochem J 287, 217-222.

12. Biolo G \& Tessari P (1997) Splanchnic versus whole-body production of alpha-ketoisocaproate from leucine in the fed state. Metabolism 46, 164-167.

13. Laurichesse H, Tauveron I, Gourdon F, et al. (1998) Threonine and methionine are limiting amino acids for protein synthesis in patients with AIDS. J Nutr 128, 1342-1348.

14. Breuille D, Bechereau F, Buffiere C, et al. (2006) Beneficial effect of amino acid supplementation, especially cysteine, on body nitrogen economy in septic rats. Clin Nutr 25, 634-642.

15. Hou Y, Wang L, Zhang W, et al. (2012) Protective effects of $\mathrm{N}$-acetylcysteine on intestinal functions of piglets challenged with lipopolysaccharide. Amino Acids 43, 1233-1242.

16. Wernerman J (2008) Clinical use of glutamine supplementation. J Nutr 138, 2040S-2044S.

17. de Blaauw I, Heeneman S, Deutz NE, et al. (1997) Increased whole-body protein and glutamine turnover in advanced cancer is not matched by an increased muscle protein and glutamine turnover. J Surg Res 68, 44-55.

18. Lobley GE, Connell A, Lomax MA, et al. (1995) Hepatic detoxification of ammonia in the ovine liver: possible consequences for amino acid catabolism. Br J Nutr 73, 667-685.

19. Mackie WS (1976) Plasma volume measurements in sheep using Evans' blue and continuous blood sampling. Res Vet Sci 21, 108-109.

20. Calder AG, Garden KE, Anderson SE, et al. (1999) Quantitation of blood and plasma amino acids using isotope dilution electron impact gas chromatography/mass spectrometry with $\mathrm{U}-(13) \mathrm{C}$ amino acids as internal standards. Rapid Commun Mass Spectrom 13, 2080-2083.

21. Lobley GE, Holtrop G, Bremner DM, et al. (2013) Impact of short term consumption of diets high in either non-starch polysaccharides or resistant starch in comparison with moderate weight loss on indices of insulin sensitivity in subjects with metabolic syndrome. Nutrients 5, 2144-2172.

22. Connell A, Calder AG, Anderson SE, et al. (1997) Hepatic protein synthesis in the sheep: effect of intake as monitored by use of stable-isotope-labelled glycine, leucine and phenylalanine. Br J Nutr 77, 255-271.

23. Lobley GE, Bremner DM, Nieto R, et al. (1998) Transfers of $\mathrm{N}$ metabolites across the ovine liver in response to short-term infusions of an amino acid mixture into the mesenteric vein. Br J Nutr 80, 371-379.

24. Lobley GE, Shen X, Le G, et al. (2003) Oxidation of essential amino acids by the ovine gastrointestinal tract. Br J Nutr $\mathbf{8 9}$, 617-630.

25. Schroder MT, Schafer G \& Schauder P (1990) Characterization of glutamine transport into resting and concanavalin A-stimulated peripheral human lymphocytes. I Cell Physiol 145, 155-161.

26. Soeters PB, Hallemeesch MM, Bruins MJ, et al. (2002) Quantitative in vivo assessment of arginine utilization and nitric oxide production in endotoxemia. Am J Surg 183, 480-488. 
27. Fong $\mathrm{Y}$, Matthews DE, He W, et al. (1994) Whole body and splanchnic leucine, phenylalanine, and glucose kinetics during endotoxemia in humans. Am J Physiol 266, R419-R425.

28. Vesali RF, Klaude M, Rooyackers O, et al. (2005) Amino acid metabolism in leg muscle after an endotoxin injection in healthy volunteers. Am J Physiol Endocrinol Metab 288, E360-E364.

29. Papet I, Ruot B, Breuille D, et al. (2002) Bacterial infection affects protein synthesis in primary lymphoid tissues and circulating lymphocytes of rats. J Nutr 132, 2028-2032.

30. Januszkiewicz A, Lore K, Essen P, et al. (2002) Response of in vivo protein synthesis in T lymphocytes and leucocytes to an endotoxin challenge in healthy volunteers. Clin Exp Immunol 130, 263-270.

31. Hellerstein MK \& Munro HN (1994) Interaction of liver, muscle, and adipose tissue in the regulation of metabolism in response to nutritional and other factors. In The Liver: Biology and Pathobiology, 3rd ed. pp. 1169-1181 [IM Arias, JL Boyer, N Fausto, WB Jacoby, DA Schachter and DA Shafritz, editors]. New York, NY: Raven Press.

32. Klasing KC \& Calvert CC (1999) The care and feeding of an immune system: an analysis of lysine needs. In Protein Metabolism and Nutrition. EAAP, no. 96, pp. 253-264 [GE Lobley, A White and JC Macrae, editors]. Wageningen: Wageningen Pers.

33. Breuille D, Arnal M, Rambourdin F, et al. (1998) Sustained modifications of protein metabolism in various tissues in a rat model of long-lasting sepsis. Clin Sci (Lond) 94, 413-423.

34. Effenberger-Neidnicht K, Jagers J, Verhaegh R, et al. (2014) Glycine selectively reduces intestinal injury during endotoxemia. J Surg Res 192, 592-598.

35. Deutz NE, Reijven PL, Athanasas G, et al. (1992) Postoperative changes in hepatic, intestinal, splenic and muscle fluxes of amino acids and ammonia in pigs. Clin Sci (Lond) 83, 607-614.

36. Lobley GE, Connell A, Revell DK, et al. (1996) Splanchnic-bed transfers of amino acids in sheep blood and plasma, as monitored through use of a multiple U-13C-labelled amino acid mixture. Br J Nutr 75, 217-235.

37. Lobley GE, Bremner DM \& Brown DS (2001) Response in hepatic removal of amino acids by the sheep to short-term infusions of varied amounts of an amino acid mixture into the mesenteric vein. Br J Nutr 85, 689-698.

38. Nieto R, Obitsu T, Fernandez-Quintela A, et al. (2002) Glutamine metabolism in ovine splanchnic tissues: effects of infusion of ammonium bicarbonate or amino acids into the abomasum. Br J Nutr 87, 357-366.

39. Kao C, Hsu J, Bandi V, et al. (2013) Alterations in glutamine metabolism and its conversion to citrulline in sepsis. Am J Physiol Endocrinol Metab 304, E1359-E1364.

40. Lichter-Konecki U, Hipke CM \& Konecki DS (1999) Human phenylalanine hydroxylase gene expression in kidney and other nonhepatic tissues. Mol Gen Metab 67, 308-316.

41. Ruot B, Breuille D, Rambourdin F, et al. (2000) Synthesis rate of plasma albumin is a good indicator of liver albumin synthesis in sepsis. Am I Physiol Endocrinol Metab 279, E244-E251.

42. Jahoor F, Gazzard B, Phillips G, et al. (1999) The acute-phase protein response to human immunodeficiency virus infection in human subjects. Am J Physiol Endocrinol Metab 276, E1092-E1098.

43. Orellana RA, Suryawan A, Wilson FA, et al. (2012) Development aggravates the severity of skeletal muscle catabolism induced by endotoxemia in neonatal pigs. Am J Physiol Regul Integr Comp Physiol 302, R682-R690.

44. de Oliveira GP, Silva JD, de Araujo CC, et al. (2014) Intravenous glutamine administration reduces lung and distal organ injury in malnourished rats with sepsis. Shock $\mathbf{4 1}$, 222-232.

45. Cruzat VF, Bittencourt A, Scomazzon SP, et al. (2014) Oral free and dipeptide forms of glutamine supplementation attenuate oxidative stress and inflammation induced by endotoxemia. Nutrition 30, 602-611.

46. Fan J, Wu L, Li G, et al. (2015) Effects of enteral nutrition with parenteral glutamine supplementation on the immunological function in septic rats. BrJ Nutr 113, 1712-1722.

47. Newsholme P (2001) Why is L-glutamine metabolism important to cells of the immune system in health, postinjury, surgery or infection? J Nutr 131, 2515S-2522S.

48. Poeze M, Bruins MJ, Kessels F, et al. (2011) Effects of L-arginine pretreatment on nitric oxide metabolism and hepatosplanchnic perfusion during porcine endotoxemia. Am J Clin Nutr 93, 1237-1247.

49. Wang L, Hou Y, Yi D, et al. (2015) Dietary supplementation with glutamate precursor alpha-ketoglutarate attenuates lipopolysaccharide-induced liver injury in young pigs. Amino Acids 47, 1309-1318.

50. Xu FL, You HB, Li XH, et al. (2008) Glycine attenuates endotoxin-induced liver injury by downregulating TLR4 signaling in Kupffer cells. Am J Surg 196, 139-148.

51. Hoskin SO, Lobley GE, Coop RL, et al. (2002) The effect of cysteine and glutamine supplementation on sheep infected with Trichostrongylus colubriformis. Proc N Z Soc Anim Prod 62, 72-76.

52. Malmezat T, Breuille D, Capitan P, et al. (2000) Glutathione turnover is increased during the acute phase of sepsis in rats. I Nutr 130, 1239-1246.

53. Bauchart-Thevret C, Stoll B, Chacko S, et al. (2009) Sulfur amino acid deficiency upregulates intestinal methionine cycle activity and suppresses epithelial growth in neonatal pigs. Am J Physiol Endocrinol Metab 296, E1239-E1250.

54. Wolfe RR \& Miller SL (1999) Amino acid availability controls muscle protein metabolism. Diabetes Nutr Metab 12 , 322-328.

55. Mittendorfer B, Volpi E \& Wolfe RR (2001) Whole body and skeletal muscle glutamine metabolism in healthy subjects. Am I Physiol Endocrinol Metab 280, E323-E333.

56. Gore DC \& Wolfe RR (2003) Metabolic response of muscle to alanine, glutamine, and valine supplementation during severe illness. JPEN 27, 307-314. 